\title{
Does Gert Biesta's book, The Rediscovery of Teaching, matter to education?
}

\author{
Tone Saevi, VID Specialized University, Norway \\ Email:tone.saevi@vid.no
}

Gert J.J. Biesta 2017

New York and London: Routledge

111 pages / 5 chapters + prologue / epilogue / index.

The Rediscovery of Teaching (Biesta, 2017) opened my eyes to what teaching is, or said differently, it taught me that teaching might more importantly address the student, so that the student lets themselves be taught. Step by step, carefully and with love and concern, Biesta leads my educational understanding into new insights. This work at its core has phenomenological qualities and challenges my own subject-ness. The Rediscovery of Teaching, inspires me to write a response, rather than a traditional book review. For this response, I want a presentation that opens the reader up to relevant questions and concerns in education, as well as an expression of my personal replies and critical concerns regarding this text. The following discussion is an intertwinement of the rediscovery of teaching, and a review that asks teachers to carefully question their practices.

The content Biesta provides the reader, including order of chapters, headings, use of key terms, degrees of heuristic devices, concreteness, distinctive rigor, strong and poignant meaning, are all exemplary, and even to some degree, phenomenologically charged. The book includes experiential material in terms of practical examples that help the reader to see the author's concerns in education. Biesta also supplies a relevant index. He adds introductory and concluding Heideggerian-like repetitions that go beyond what is previously said in the chapter. By this he leads me not only to grasp the book's message, but also allows for a deeper understanding. The book is classified as a theoretical contribution to education, yet Biesta's text gratifies the core qualities of $P \& P$ 's scope. Biesta manages to merge educational theory and phenomenological qualities of concreteness and openness, drawing these entities closer in a shared interest of providing alternatives to contemporary education. This book even enriches phenomenological insights, by its direct ethical and political concern for education. Phenomenology depends on these kinds of theoretical insights to formulate relevant questions for phenomenological investigations, and this book is particularly useful in generating insights, allowing the reader to deconstruct the educative guarantee, providing new questions, angles and perspectives. Biesta is not concerned with convincing the reader that 
education has become a lost practice; rather he explores the phenomenon in a self-critical way and thus sustains subjective thinking and being.

Biesta's opening statement: "The point I seek to make in this book is that teaching matters" (p. 1) and he manages to make his case in a relatively thin, succinct read of a little more than 100 pages. Despite the concise read, this is an extraordinarily rich and substantial text for those invested in education. Teaching matters is a popular claim today that is still debated. Although a negative populist narrative perhaps is the most common today claiming teachers are not good enough and that this is the main problem for educational governance striving for efficient managed perfection, Biesta argues for a third way of thinking about education, different from the what we have come to know, breaking away from our neoliberal immersion. This alternative is disturbingly simple, yet convincingly complex showing what makes education educational. From the reviewer's perspective this argument answers the questions: Does The rediscovery of teaching matter to Education?

Initially, Biesta asserts that the real issue is not whether teaching matters or not, but how teaching matters and what (and to whom) teaching matters. This point is important: how something matters and for whom does it matter. Why? This has to do with humanistic purposes and relationality countering measurements of teachers and students as performative results and rationality - a difference that matters more to teachers and parents, and to children and young people. According to Biesta, there is a need for a third way of thinking about education - a rediscovery of what teaching is about - to open a highly relevant and provocative discussion about what freedom is, or to be more precise, what does freedom mean for children and young people, and whether freedom still is an educational concern. This is not a new problem, considering the freedom of the next generation has been an issue in European, as well as North American education for centuries. However, the Bologna agreement in 1999 has re-actualized dilemmas and dimensions of freedom in Europe. One of the recent dilemmas of education is a rise of the corporatized language of learning, and with this, the role of the teacher has been put on the table again and again. The teacher has been transformed from a " 'sage on the stage' to a 'guide on the side' - a facilitator of learning...to a "peer on the rear"' (p. 1). The one-dimensional focus on learning has produced practices of defining learning outcomes and a global measurement industry (Biesta 2010), along with strong ideas of what a good citizen is and what constitutes a life-long learner, and how governments use randomized statistics to control, verify and select educational qualities. The issues of a new kind of control and authoritarianism limit students', and teachers', possibilities for being subjects, as they are all objects subjected to control that organizes education from the outside.

Biesta's intent with this little book is expressed as "a set of progressive arguments for what is nowadays generally seen as a conservative idea" (p. 3), and his arguments present a third option to the conservative (traditional) view of teaching that is blacklisted and opposed by liberating and progressive child-centered and student-centered conceptions of education. Instead of the idea of a liberating freedom of choice and self-realization, Biesta presents a more difficult freedom, which he describes as "the freedom to do what only I can do" (p. 5). He suggests that teaching should be based on dissensus - the experience of disagreement in opinion - the available evidence pointing in opposite directions. Teaching as dissensus, is asking the impossible, refusing incompetence and looking for an open and unforeseen future for students. This unforeseen, possible future - unknown, un-anticipated - is what might open up a space where the student's subject-ness, that which only they can do, that which makes them irreplaceable in the world. Biesta tries to show how teaching might be oriented toward opening up existential possibilities "through which students can encounter their own freedom, can encounter the 'call' to exist in the world in a grown-up way, as subjects" (p. 6). 


\section{What is the Educational Task?}

How do I as teacher arouse the desire in a child or young person for wanting to exist in a grown-up way in and with the world - to exist as subject? Teaching, Biesta says, is not just any job among jobs, but comes with a particular responsibility or imperative, given to the teacher as a gift. The educational task, as Biesta expresses "consists in making the grown-up existence of another human being in and with the world possible" (p. 7). This is the difficult freedom, not just because the task to arouse the desire to exist as a subject is hard for the teacher to actually do, but because children and young people not necessarily want to be grown-ups or actually see the point of being subjects to themselves and others. What does Biesta mean by being a grown-up and what does it mean to exist? To start with the latter, existence according to Biesta is a "wish to focus on the ways in which human beings exist...on how they are, and not on the question of who they are" (Italics in original, p. 8). Who I am is a question of identity, while how I am is a question of subjectivity. These are very different questions and should not be confused or conflated, neither as concepts nor with regard to what they mean. How I am has to do with my irreplaceability as person and is a first-person matter. How I am, act, orient, is a matter of my uniqueness, my way of being in the world, and my way of seeing the world. Being in the world in a grown-up way is to acknowledge the alterity and integrity of what and who is other, whereas in the non-grown-up world this is not "on the radar," Biesta says (p. 8). The grown-up way of being a human being does not have to do with age - all ages might acknowledge alterity - the crux of the matter is whether we acknowledge others and the world as neither a world of our own making or a world at our disposal or for our greedy use. We are not in the position to decide about the world. We are not at the center of the world - indeed we are in the position of being datives of the world (Sokolowski, 2000). Being a teacher or parent is not one-dimensional with a rather good chance to succeed. Upbringing like teaching is doomed to fall short, fail, be unsuccessful, more than to succeed, and the grown-up will by necessity have to bring up themselves rather than bringing up or teaching the children of their responsibility. The complex pedagogical question is how we bring up and educate children by being humans that strive to be human beings dwelling with them as life comes to us.

Contemporary education is exactly about the strong and independent individual freedom - however illusive this freedom might be existentially - and not about dependency and weakness. Biesta, however, shows that the human being has the capacity to initiate actions. As human beings capable of action, means we also suffer from the consequences of that same action and are subjected to how it is taken up by others. Our subject-ness therefore is not in our own hands, but a quality, or rather a human condition that is dependent on other persons. The problem with trying to master the world by controlling other people's actions and responses is that we then deprive them of being subjects too. Subject-ness is exactly about how my subjective way of being in the world might make a difference. "When does it matter that I am I?", Biesta asks (p. 12). This is not a question "about everything I have or possess that would distinguish me from others, but looks for situations, for existential events, where my uniqueness is 'at stake' and $I$ am therefore at stake" (Italics in original, p. 12) This is, in other words, about my response to situations when the world calls on me, speaks to me, and when it matters what I do (or not do).

We encounter a responsibility that springs from my irreplaceability when someone or something asks for my attention, my action, my response. The responsibility, however, is not a duty or a biological disposition, but human freedom. We can walk away, let the challenge remain, and we could refrain from taking responsibility for another persons' responsibility. If we respect others as subject to their own actions rather than objects to our own, we have to let them decide whether they respond or not - a resistance that is up to me to respect. Biesta 
emphasizes the un-sentimentality that unties the responsibility for others from my inner feelings or needs to care for others. Biesta's intent is educational:

The encounter with resistance, that is, the encounter with the fact that something or someone resists our initiatives is a tremendously important experience as it shows that the world is not a construction of our mind or our desires, but actually has an existence and hence an integrity of its own. (p. 14)

Resistance comes from others and from the world itself and tells us that we are in a world with others that all have their own existence and integrity. This insight is at the very heart of how we are responsible for our encounters with the next generation. Biesta's concern is how we as adults; teachers and parents, might point to the worldly existence for children and young people, and appeal to their desire to want to be there, in the world, with others, on the condition that this is the world they actually have.

There are other alternatives - Biesta presents them as world-destruction: the desire to master, control and push my will through to the degree that the world breaks, and selfdestruction; the inclination to withdraw or even destroy oneself. There is the inclination to avoid resistance and withdraw from the complexities and controversies of the world into a smaller and more manageable world of my own. Both world-, and self-destruction are wellknown educational issues, but what kind of human society do they support? Biesta asserts that human existence only is possible in the middle ground between the extremes; because only here can our self-expression encounter limits, interruptions, and responses. Only here can what I do matter for someone, and only here might my irreplaceable subject be at stake with others. Only here, do I encounter the responsibility that calls me to action, and only here, am I interdependent of others in the real reality where we both exist as subjects. Biesta relates being a grown-up - the ultimate result of education - not to age or position, but to the (teacher's and student's) willingness and desire to reality check their desires to see if they are desirable - not only for themselves - but also for the world and the humans outside their egological sphere. Whether our desires are acceptable to others, and in the long term truly desirable, or not, is educationally important and poses itself as an "interruption of our desires" (p. 16). The educational endeavor is to "give them [the desires] a worldly form and quality so that they can support and sustain a grown-up way of being in and with the world" (p. 16). However, as Biesta points out, education is opposed by the very society in which we live - the impulse society - and peruse our desires to the highest possible degree to fulfill them and constantly produce new. Education should basically be an interruption of our egocentric immanence - destroying the belief that any educational development is good, based on learning and desire, and that learning is good in itself, and the inclination to believe that education is to further develop a full potential of children's talents. Making the question of desirable desires alive in children and young persons, presupposes that the same question is a living question in the life of at least one of the adults significant to the child. How do we do that? We should reeducate our desires for things and rediscover the love for all that is living, because all that is alive is a fundament for our own survival on earth. The point is that we must start with ourselves before we support others.

\section{Freeing Teaching from Learning}

The key question raised by Biesta is the relationship between teaching and learning, and he warns us that tying teaching and learning too closely might prevent us from seeing existential opportunities that might occur in the present situation or relation. Biesta asks a list of questions, initially questions that are well known and easy to follow, but then perhaps to some, also unexpected questions: "does teaching necessarily lead to learning? Should the sole ambition of teaching be to promote or bring about learning? Can we assume that teaching 
causes learning" (p. 22)? Then the harder questions: "Is it a relationship between the meaning of concepts, so that to use the word 'teaching' without assuming the word 'learning' makes no sense? Are 'teaching' and 'learning' necessarily connected? Is it possible to think of teaching outside of the confines of learning" (p. 22)? And the really hard ones: "Can teaching be meaningful if it explicitly tries to keep students away from learning? And for what reasons might this be a good idea" (p. 22)? Questions of the relationship between teaching and learning go to the heart of education, and therefore are decisive for thinking and practicing education. The responsibilities of the teacher are also at stake in answering these questions: what if the relationship between teaching and learning is not a cause-effect relationship and the teacher's responsibility for learning outcomes are more ambiguous than we tend to believe? Biesta asserts that key educational questions regarding the purposes of teaching and of education more widely, are precluded and marginalized by the intense focus on learning and production of knowledge and outcome in contemporary education. Consequences of this is that being a learner includes being an object of teaching, a receiver, a consumer, rather than a subject addressed by existential questions from the outside that call for the responsible grown-up qualities of the child and young person.

Biesta heads into the question of the teaching-learning-connection by exploring various relevant English-speaking-world related views to how the relationship is understood. When looking at the meaning of the word learning, most would agree that some kind of change is related to learning, but is the change related to the process or to the outcomes of learning? Should learning be connected with what students do? Do students for instance look in particular ways when they learn? Biesta introduces a shared responsibility between the teacher and the learner for the outcome of teaching, and a step further is taken. The teacher is here not responsible for what the student actually achieves, but for the activity of "studenting" (p. 27). English-speaking educational theorists, consider learning the end-result of education, and here Biesta disagrees: "The language of learning is insufficient as an educational language" (p. 27) and "Unlike the language of learning, a language of education always needs to pay attention to questions of content, purpose and relationships" (Italics in original, p. 28). To Biesta the question of purpose is the most important of the three. To me the question of relationship is so central to purpose that it cannot be omitted without purpose of education being more or less meaningless. The reason is that if education is an existential endeavor, the human being is an underlying feature, although the human being should not be at the center, he or she is still the source of existential experience and is the subject of as well as subjected to education.

Education is always related to some ways of being and doing, some tradition, ideology, belief or worldview. Education functions within three domains, as purpose, content and with regard to the relation between adult and child, and Biesta calls the educational domains qualification, socialization, and subjectification. Teachers are faced with the challenge to find a meaningful balance between the three domains, as a focus on one domain might limit or interfere with the others.

The function of education as qualification, socialization and subjectification gives education its direction. This balance is disturbed with a sole focus on students' learning and a mis-balance on qualification without other aims than a measurable outcome. The learningregime is a political regime, according to Biesta (pp. 29-30). Learning is in general considered unavoidable; we always learn and cannot escape learning. Children and young people, however, increasingly are expected to adapt to a commonly accepted capitalist ideology, "in the service of a global capitalist economy that is in need of a flexible, adaptable and adjustable workforce" (p. 30). Political problems are being turned into educational problems that education is expected to solve. Being a learner is all about understanding, rationality, sense-making, and paradoxically, the learner is at the center of the world at the 
same time as the learner is a tool for a political system. The existential and human problem thus is, that the child, in this system is expected to turn the world into an object, and existential questions regarding the natural and the social world become invisible, unspeakable, and outside our attention. This is of course not either or, but being oriented to learning as comprehension weakens the possibility to experience that the world addresses me or interrupts me with existential concerns. While at the center of the world I am not aware of other voices or needs; others do not disturb me.

Educationally, how we understand our relationship to the world and others, has consequences for how we practice teaching. Epistemology - how we understand, make sense and comprehend ourselves, others, and the world - has wide consequences for how we live in and with the world. Thus epistemology, ontology, and methodology are intertwined conceptions without clear borders. Living in a world that exists for me, is my object of interest - where I master the world by being the constructor of it, and constantly, compete with others in this system - is not the only alternative. Biesta's suggestion of three ways of being the world; as world-destructor, self-destructor or as grown-up (p. 14), is helpful to understand this. Knowing as an act of construction, or living as something irrelevant and dangerous that one decides to withdraw from, is very different from living in a world as a human being on equal premises as others. Knowing might be an event of reception (p. 33), and Biesta presents these as alternatives for education. How can we teach children (and ourselves) a way of being receptive (in contrast to intentional) and passive (in contrast to active) towards the world, and by this, allow the world to have "its own integrity" (p. 33)? Our existence as subjects is not in our own hands, but emerges in response to something that addresses and interrupts us from the outside, from the world that is different from ourselves and challenges our ways and views. How do we teach ourselves and our children, to listen, be receptive, open themselves up, so that what comes from the outside can address them? This is a very different attitude than mastering, being in control, compete, and construct the world, and what comes from others.

Biesta tries to think at the borders of educational thinking, and asks what it might mean to teach without wanting or intending the students to learn. Learning is not always good and desirable, and many contemporary examples tell us that intelligence, knowledge and skills equally well might be used for evil purposes, as well as for good. Education is not a neutral endeavor, and being a productive learner is not necessarily good either for the person or for society. "Is it possible in our work with students, to take learning out" (p. 34)? Biesta asks, "And if we do so, if we teach without aiming for learning, would this still amount to something that is educationally meaningful" (p. 35)? Biesta shares an experience from his own teaching where he tried to take learning out, and to me the very thought - which I admit is not new to me although Biesta forms it without preconditions - prompts how I see my own previous, present and future teaching. I began to think of teaching that I felt was futile or at least questionable, not because it was bad or because I did something pedagogically or ethically wrong, but because I never told any of my teacher colleagues about it - it remained something between me and the students. But why? It could be that I did not grapple enough to find educational words for my actions, was I embarrassed, or was I simply unaware of the educational value of my action or lack of action? What I have decided however, is to write a phenomenological reflection about educational blindness, and how naivety might contribute to students' sense of freedom based on examples of my own seemingly fruitless teaching (Saevi, forthcoming).

\section{The Rediscovery of Teaching}

The third chapter starts with, and urges teachers and students not simply unthinkingly to focus on learning and comprehension, but to try to attend to education in other ways. Biesta 
introduces a distinction between interpretation as comprehension, and an existential alternative. Biesta considers that teaching is not "a limitation of the freedom of students but the very way through which the student-as-subject emerges" (p. 41). Initially he asserts that the critique of traditional teaching in itself is traditional, and that educational practice today is not just trivial, but even running out of breath. A core of the critique of traditional teaching is the lack of freedom due to a rather authoritarian teaching style - the traditional one-way lesson - but what is forgotten here, is raised by Biesta by shifting the focus from learning to teaching and asks the existential (and phenomenological) question: what is the "experience of being taught" (p. 42)?

If traditional teaching is accused of being authoritarian and neoliberal teaching aims at being the opposite, what then is the role of the student, and more important the experience of the student? As educational theory and phenomenological pedagogics meet here, the crucial question of how teaching is experienced - or, how being taught is experienced - is a much wider question than a question belonging in schools. One might consider phenomenology even more democratic than education in that a phenomenon (like being taught) can be found everywhere in human life and is open to every experience of it in real life, as well as in art, dreams, hallucinations or imagination. The hermeneutic aspect is related to the strong focus on students' sense-making and comprehension of the world - the object of our subjective interpretation. Presuming that what one sees and understands is true, the question of what is not seen, attended to, or even the un-seeable or unthinkable, is irrelevant. Here Biesta's use of the terms immanent, and transcendent makes sense; the immanent universe means that the world out there always is brought back to me in my comprehension and interpretation of it, while transcendence allows what is out there to stay different from me, be not in my hands, although it might address me and I might explore and let myself be invited in. Biesta considers immanence in this meaning of the word to be an objectification of what is other, while transcendence is the opportunity for the subject to encounter what is other without assimilating it and make it the same. A commonly accepted didactical principle - teaching is about trying to grow and deepen what is already there in the student, and to incorporate new knowledge into the already existing. This, in short, means that teaching as an existential and ethical event is about giving without expecting to receive anything in return from the students, not even learning, comprehension or results. Teaching is in part "uncompensated work" ( $p$. 28). Thinking like this changes the task of teacher and the student, to that of interlocutors those who express something in relation to another.

The other is not the same as me, or my product, interpretation or construction. The other, the student (as with the teacher) is other - the one addressed by me and the one who addresses me. This is a decentering of my ego, and my consciousness "loses its first place" ( $p$. 32). Instead, the other calls me, addresses me, speaks to me, and I can respond or not - herein lies my freedom. This means that communication and relationships are not exchanges of opinions or views, but responsible events coming from the outside addressing the ego, and most important, anchored in reality. The educational concern is the question of how the student can appear as a subject, meaning how the subject might be interrupted by something or someone other, and not keep the self to its sufficient self. While being a learner is adapting to a stimulating and sense-making learning environment, being a subject is different. Being a subject is to allow the other to interrupt my self-sufficient and ego-logical way of life, and to be attentive to the otherness that addresses me from the outside world. Biesta suggests that the moment when the other addresses me and this other asks for something that only I can do, might be the decisive educational moment. 


\section{Don't be Fooled by Ignorant Schoolmasters}

Biesta orients the reader to emancipation, and teaching as an endeavor to open the student to his or her possible freedom. What does this mean, and how do we as teachers think and act to promote an education that might open up a possible freedom to students? Biesta argues, in line with Ranciere (1991), that the key message is that "emancipatory education is not a matter of transfer of knowledge from a teacher who knows to a student who does not (yet) know, but nonetheless is a process in which teachers and their teaching are indispensable" (p. 60). He then heads into the task of why and how teaching is indispensable for emancipatory education, and why teachers, whether very knowledgeable or not, are necessary if education should be education worthy of the word.

Biesta strolls through the various views of freedom that have influenced the contemporary logic of emancipation, from the Greek paideia - Bildung - and the existence of being or becoming autonomous subjects. Then he focusses on the development of emancipatory education into respectively child-centered and society-centered education, and toward critical Marxist standpoints being core after WW2. The modern logic of emancipation interprets emancipation as liberation from power, and the focus in particular is that emancipation can be given to someone, and can be fully obtained in the future. In education the teacher can either restrict the students' emancipation, being limited to a facilitator, or the teacher is the one who knows the objective condition, under which we all live, and when the students reach the level of the teacher, they are equal. "This means that the modern logic of emancipation starts from a distrust in the experiences of the one to be emancipated, suggesting that we cannot really trust what we see or feel but need someone else to tell us what is really going on" (p. 63). A conflicting factor is that as human beings we are immersed in life and culture and cannot escape, and as Biesta states, contemporary ideologies are powers that "work upon our consciousness [so] that we are unable to see how power works upon our consciousness" (p. 62). The point so far is that the teacher constantly should orient to students as subjects of possibility rather than as objects of learning, and that the teacher in this verification of the student, acts as if the student's ability and willingness are true. By this the acts will have the chance to become true.

Considering emancipation a question of the will rather than of knowledge, is revolutionary to contemporary thinking of education, and might have the potential to open up new possibilities to the impossible and insolvable inclusion dilemma. Equality of students would have to be seen in new light, relational and democratic practices might get better conditions, and humanity as an educational aim would be a possibility for more children and young people. Biesta states that by recapitulating the three conceptions of emancipatory education: liberation, truth and teaching (p. 73). Liberation is oriented to liberation from power and the teacher's task is to tell the student the truth about what and who are oppressing him or her, and, as Biesta sees it, is to provide us with an argument for teaching rather than learning (p. 75). In my entire academic life, I have believed a particular truth about emancipation. The heretical thought has managed to sneak into my consciousness, I along with other educators, might have been trapped in the modern assumption that someone in fact has the truth, and that this truth is what I need to become free. A captivating, but - I realize now - too simple assumption. A teacher does not have to have the truth to be a good teacher. In fact, the teacher is a real teacher if he or she intends to open up the world to children and young people by showing the world to them and asking them to look at it with their own eyes and from the possibilities offered to them by the life they live in this world. This is a phenomenologically meaningful and emancipating insight that reveals the existential significance of a subjective access to the world's phenomena.

The point is that learning (knowledge) and emancipation are not connected. Emancipation is a totally different domain that is not easily obtained or perhaps for many not 
even wanted because it comes with a responsibility for the world. This does not mean that teachers should not be knowledgeable, but it means that "knowledge is not the way of emancipation" (Italics in original, p. 76). The emancipated subject has the capacity to inscribe him or herself "in the political project of equality" (Italics in original, p. 76). However, if emancipation is about using one's own intelligence; inscribing oneself in the political project of equality, rather than simply relying on others' knowledge as truth, why is then a teacher required for a student to be in a process of emancipation? Biesta argues that a teacher's responsibility comes in play when "students... of any age deny or refuse this option, whether by claiming that they are unable to think and act for themselves or by expressing that they are unwilling to think and act for themselves" (p. 76).

\section{Asking the Impossible: Teaching as Dissensus}

Biesta formulates what he believes education is about "arousing the desire in another human being for wanting to exist in and with the world in a grown-up-way, that is, as a subject" (p. 82). According to Biesta, this is not one of many options, but the task that is given to us. It is the task we are charged with, responsible for, the mission we have to carry when we encounter a child coming into the world or a student in the classroom. Surviving as the first desire for the human being which is followed by living one's life in a particular way by existing as a human being. The educational task is to help children and young people to live their lives in subjective ways that allow others to live their lives with integrity and in their own right. To exist as grown-ups in the world has to do with being open to other people's otherness in manners that do not suppress or destroy their integrity, but to be in dialogue with them and be willing to allow their otherness to be part of one's own life (Saevi, 2015).

Biesta recapitulates that teaching has emancipatory potential as it interrupts my selfabsorbedness and opens me to the existence of others and the world, in "the act of teaching" (Italics in original, p. 83), the particular quality in teaching oriented towards the subject-ness of the other, the moments when it makes a difference that I am unique and irreplaceable. Biesta calls the quality of teaching an act of dissensus. Dissensus here does not mean opposition or disagreement, but rather alludes to understand the impossible.

Teaching as dissensus...can be seen as a way of asking the impossible of a child or student if, that is, we do not think of the impossible as what is not possible, but rather conceive of it... as that which cannot be foreseen as a possibility, cannot be calculated or predicted from here and now. (pp. 83-84)

Teaching as dissensus is precisely oriented to that which is not seen, not present but might be a hope or belief for this child, although not related to the verified situation of knowledge or skills. We do precisely not build on what the child already knows, but suggest something more important for this child to become a subject, a person that has their own will, a grownup-ness and is open to encounter the world outside his or her comfort zone. Biesta puts forth a challenge to teaching as dissensus - or in more general words he puts at stake "the educational about education" (p. 89). Time in education commonly has to do with learning and change. Learning leads to change and change takes time. Change is related to development, growth and progress, and we think of education within a linear conception of time, where the measurement of learning results and the economy of school time, are core. The child in this picture is "not yet," "in development" and is in "need of education" (p. 88), in order to develop properly. Biesta argues that this "is a colonial way of thinking in which the other (the child, the learner) is defined as lacking and as 'being-in-need-of' so that the educator can be in a position to fill the lack and meet the need" (Italics in original, p. 89). However, can we think differently about teaching, and why would we want to?

If we work from the assumption that teaching is going to make a student more competent, we think of teaching as concurrence - agreement, consent - rather than as 
dissensus, and work perfectly within the educational modes of qualification and socialization. The student will learn, develop and require skills and knowledge, but remains an object and will not be a subject in his or her life. Unlike knowledge and skills, subject-ness is not something that a person can possess, but is an event that may or may not occur. Instead of empowerment, as subject-ness is not the result of a trajectory of learning, but "an event that breaks through all this irrespective of whether the child - or anyone of any age, for that matter - is ready for it or not" (p. 91). To bring about subject-ness in another person then calls for trust in that person - a trust without reason or evidence - a trust that puts their subject-ness at stake" (p. 92). Biesta even asserts that not knowing students is a good thing in teaching because we then free the students from their past (i.e. history, problems, diagnoses), and might be able to approach them in new and unimagined ways. Tying the students to that which is - be it a competence or lack thereof - places the burden of education on the student rather than on education and on the educator's imagination to find out how to teach.

Biesta suggests that teaching is about seeing what is not visible and not seeing what is visible (p. 94). Students' subject-ness is not a visible quality recognizable in behavior or language, but needs faith, hope, imagination, and interruption, to enter the scene and become a momentary living reality. The challenge of teaching as dissensus is precisely to believe in, and earnestly trust the student's willingness to be a subject, and if the student insists on being an object to education, similarly insist on the student being a subject that (although gradually) is willing to take on the responsibility for letting alterity and otherness find a place in their life. According to Biesta, this is not a once and for all event, but rather a way of living in the world that is a constant challenge. Arousing the desire in children and young people to live in the "middle ground" of the world is hard work and should not be taken lightly in education.

In The Rediscovery of Teaching, Biesta reveals immensely complex insights in what education means and how educational qualities in education cannot be easily obtained or measured. The problems discussed go directly to the heart of education and to what it means to be a teacher. Teaching should be given back to education because teaching precisely has something indecisive to do when it comes to the freedom of the child and student. Freedom, not the opposite, which in a Mollenhauerian (2014) terminology is called "educational imprisonment," is the basis and practice of emancipatory education. Human freedom, freedom as action, the difficult freedom, is the freedom we encounter as teachers. In my thinking, teaching is a responsible gift that we encounter rather than chose when children and students show up in our lives. Hence, the challenge to live in the middle ground oneself - as a teacher or adult - is perhaps the hardest life effort to take on, and the way of living that is most tempting to try to avoid. The alternatives are much easier and at least at times, comfortable.

\section{References}

Biesta, G. J.J. (2006). Beyond learning. Democratic education for a human future. Boulder: Paradigm Publishers.

Biesta, G.J.J. (2010). Good education in the age of measurement. Boulder: Paradigm Publishers

Biesta, G.J.J. (2011). The ignorant citizen: Mouffe, Rancière, and the subject of democratic education. Studies in Philosophy and Education, 30(2), 141-153.

Biesta, G.J.J. (2012). No education without hesitation. Thinking differently about educational relations. In C. Ruitenberg et al. (Eds.), Philosophy of education 2012 (pp. 1-13).

Urbana-Champaign, IL: PES. 
Biesta, G.J.J. (2015). Hva er en pedagogisk oppgave? Om å gjøre voksen eksistens mulig. In: P.O. Brunstad, S.M. Reindal, \& H. Sæverot, (Eds.), Eksistens og Pedagogikk (pp. 194-209). Oslo: Universitetsforlaget.

Biesta, G.J.J. (2017). The rediscovery of teaching. New York and London: Routledge.

Biesta, G.J.J. (2019). Obstinate education. Reconnecting school and society. Leiden/Boston: Brill Sense.

Langeveld, M. (1983). Reflections on phenomenology and pedagogy. Phenomenology + Pedagogy, 1(1), 5-10.

Mollenhauer, K. (2014). Forgotten connections: On culture and upbringing. London/New York: Routledge.

Ranciere, J. (1991). The ignorant schoolmaster. Stanford, CA: Stanford University Press.

Saevi, T. (2015). Ansvar for eget ansvar. Å gi barnets eller den unges annerledeshet plass I mitt liv. In: P.O. Brunstad, S.M. Reindal \& H. Sæverot, (Eds.), Eksistens \& Pedagogikk (pp. 73-91). Oslo: Universitetsforlaget.

Saevi, T. (forthcoming). Reality-testing subjectivity, naivety and freedom - or on the possibility of educational moments. In P. Howard, T. Saevi, A. Foran, \& G. Biesta, (Eds.), Phenomenology and educational theory in conversation: Back to education itself. New York: Routledge.

Sokolowski, R. (2000). Introduction to phenomenology. Cambridge, UK: Cambridge University Press. 